\title{
MIELISAIRAALAPOTILAS? Poikkeavuus ja erilaisuuden rajankäynti elokuvassa Prinsessa
}

\begin{abstract}
Mielisairauksista kärsivien ihmisten toiseuttamisella on länsimaisessa kulttuurissa pitkät perinteet. Audiovisuaalisen median tuotteet, kuten elokuvat, ovat usein asettuneet osaksi tätä jatkumoa, sillä ne ovat toistuvasti uusintaneet esimerkiksi mielenterveysongelmien ja väkivaltaisuuden yhteyttä. Erityisesti parin edeltävän vuosikymmenen aikana audiovisuaalisen median välittämissä mielisairauden representaatioissa on kuitenkin alettu nähdä merkkejä aiempaa myönteisemmistä tulkinnoista. Artikkelin aineistona toimiva kotimainen draamaelokuva Prinsessa on yksi tuoreimmista, 2000-luvulla tuotetuista mielenterveyden problematiikkaa käsittelevistä audiovisuaalisen median tuotteista. Sen kerronnassa tapahtuva erilaisuuden rajankäynti avaa mielenkiintoisia näkymiä menneisiin ja eritoten nykyisiin mielen sairauksia ja poikkeavuutta koskeviin kulttuurisiin tulkintoihin.
\end{abstract}

Prinsessa (2010) on tositapahtumiin pohjautuva elokuva Prinsessaksi itseään nimittävän naisen elämästä Kellokosken mielisairaalassa pääasiassa 1940-50-lukujen taitteessa. Elokuvan mainosjulisteessa ja DVD:n kansissa elokuvaa markkinoitiin puhuttelevalla retorisella kysymyksellä: "Prinsessa - onnellisempi kuin yksikään meistä?" Kysymys on mielenkiintoisen hämmentävä, sillä siinä rinnastetaan asiat, joiden kulttuuriset merkitykset ovat miltei päinvastaiset: myönteiseksi miellettävä onnellisuuden mahdollisuus yhdistetään ihmiseen, joka mielisairaalapotilaana edustaa historiallisesti ja kulttuurisesti pitkään poikkeavana ja puutteellisena pidettyä ihmisryhmää, toiseutta. Olisiko siis niin, että Prinsessassa pyritään pohtimaan ja kommentoimaan psykiatrisiin potilaisiin liittyvää toiseuttamisen traditiota?

Länsimaisen populaarikulttuurin edustajana Prinsessa ${ }^{1}$ kiinnittyy osaksi muita mielenterveyden tematiikkaa käsitteleviä televisio-ohjelmia ja elokuvia, joista tunnetuin esimerkki lienee menestyselokuva Yksi lensi yli käenpesän (One Flew Over the Cuckoo's Nest, USA 1975). ${ }^{2}$ Mielisairauden esittäminen audiovisuaalisen median kontekstissa nousi akateemisen kiinnostuksen kohteeksi 1950-luvulla (ks. esim. Gerbner 1959). Tällöin televisioiden yleistyminen synnytti edelleen ajankohtaisen kysymyksen siitä, millainen vaikutus niiden
1 Kun viittaan elokuvaan, käytän kursiivia (Prinsessa) läpi tekstin erotuksena elokuvan päähenkilön nimeen (Prinsessa).

2 Suomessa muita samaa teemaa käsitteleviä tai sivuavia elokuvia ovat esimerkiksi Palava enkeli (1984), Koirankynnen leikkaaja (2004) ja Putoavia enkeleitä (2008). Televisiossa aihetta on käsitelty viime aikoina Salatuissa elämissä (2009-), jossa mielisairaudesta on tullut erityisesti parin edeltävän vuoden aikana toistuva teema mielenterveydeltään epävakaaksi kuvatun Marianna Kurjen (Oona Kare) henkilöhahmon myötä. 


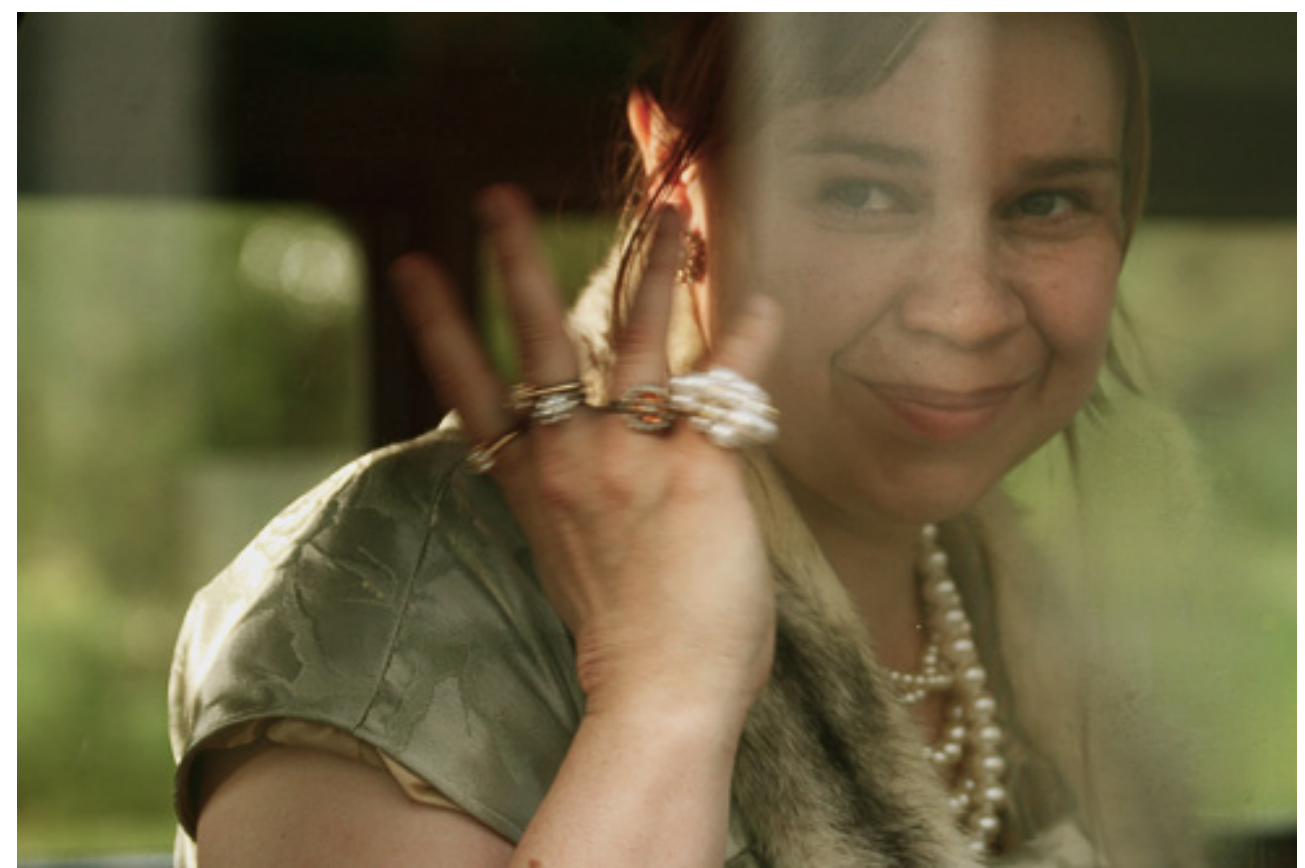

"Prinsessa - onnellisempi kuin yksikään meistä?" Kuva: @ Art Films Production, kuvaaja Terhi Kokkonen.

välittämillä representaatioilla on psyykkisesti sairastavia ihmisiä koskeviin asenteisiin. Suomessa kysymys on jäänyt verrattain vähälle huomiolle, mutta edeltävissä kansainvälisissä, erityisesti 1900-luvun puolelle ajoittuvissa tutkimuksissa on osoitettu toistuvasti, että psyykkisesti sairastavat ihmiset kuvataan audiovisuaalisessa mediassa huomattavan usein esimerkiksi vakaviin väkivaltarikoksiin taipuvaisina henkilöinä (ks. Signorielli 1989; Diefenbach 1997). Tämän on todennettu vaikuttavan negatiivisesti mielenterveyshäiriöitä ja psyykkisesti sairastavia ihmisiä koskeviin käsityksiin (ks. Domino 1983; Wahl \& Lefkowitz 1989). 2000-luvulle tultaessa on kuitenkin alettu esittää myös tulkintoja, joiden mukaan mielenterveysongelmien kuvaus audiovisuaalisessa mediassa olisi muuttumassa aiempaa myönteisemmäksi (ks. Harper 2008; Mullins 2014). ${ }^{3}$

Ensisilmäyksellä Prinsessa näyttäisi representoivan aihettaan verrattain positiivisesti: sen mainoslause ehdottaa mielisairaalapotilaan ja onnellisuuden yhteyttä, eikä elokuvassa myöskään näkyvästi uusinneta esimerkiksi mielenterveysongelmien ja väkivaltaisuuden kytköstä - aivan kuin totunnaiset kulttuuriset merkitykset ja mielikuvat olisivat siis liikkeessä, poissa totutuilta sijoiltaan. Tässä artikkelissa pureudun Prinsessassa tapahtuvaan erilaisuuden rajankäyntiin tarkemmin. Viittaan erilaisuuden rajankäynnillä kyseisessä elokuvassa - sekä mediassa ja kulttuurin eri tahoilla laajemminkin - käytävään sosiaaliseen neuvotteluun asioiden ja ilmiöiden sekä ennen kaikkea yksilöiden ja ihmisryhmien ominaisuuksista, keskinäisistä suhteista ja eroista. Tässä neuvottelussa konstruoidaan käsityksiä yhtäältä siitä, mikä on odotuksenmukaista ja normaalia, sekä toisaalta siitä, mikä on epäsopivaa ja puutteellista, toisin sanoen poikkeavaa. Länsimaisen kulttuurin kontekstissa mielen sairauksista kärsivät ihmiset on usein tulkittu ja esitetty poikkeaviksi toisiksi, joiden yksinkertaistettuja piirteitä vasten käsityksiä normaalina, ihanteellisena ja terveenä pidetystä on tuotettu.
3 Yhtenä esimerkkinä audiovisuaalisen median emansipatorisesta otteesta on tarjottu elokuvaa Kaunis mieli (A Beautiful Mind, USA 2001). Elokuva pohjautuu skitsofreniaa sairastaneen todellisen historiallisen henkilön, Nobelpalkitun matemaatikon John Nashin elämään (ks. Mullins 2014; ks. myös Hämäläinen 2007). Televisiosarjojen osalta esille on nostettu Suomessakin nähty Monk (USA 2002-2009), jossa etsivän työtä tekevän päähenkilön, Adrian Monkin (Tony Shalhoub), lukuisia fobioita ja pakko-oireita ei kuvata korjausta vaativina puutteina. Sen sijaan ne esitetään Monkin identiteetin olennaisina osina, joilla on sarjassa positiivisia seurauksia (ks. Johnson 2008, 39, 44). 
Tavoitteenani on selvittää, millaisia normaaliuden ja poikkeavuuden välisiä rajanvetoja Prinsessasta on hahmotettavissa. Kysyn, kuka tai mikä elokuvassa oikeastaan esitetään poikkeavaksi ja miten poikkeavuuden ja normaaliuden rajoja tuotetaan ja ilmennetään. Lisäksi pohdin elokuvaa suhteellisen tuoreena, 2000-luvulla tuotettuna mielenterveyden problematiikkaa käsittelevänä representaationa, ja kysyn, mitä elokuvan voisi ajatella viestivän mielenterveysongelmia ja poikkeavuutta koskevista käsityksistä nykykulttuurissa.

Tekstini paikantuu kahteen osin limittäiseen tutkimustraditioon: yhtäältä poikkeaviksi miellettyjen ihmisryhmien ja median suhdetta tarkastelevaan tutkimussuuntaukseen (esim. Cross 2004; Birch 2011; Rantala, V. 2013) sekä toisaalta ennen kaikkea ajankohtaiseen humanistis-yhteiskuntatieteelliseen hulluustutkimukseen, jossa huomio on poikkeavuuden kohtaamisen, nimeämisen ja käsittelyn kulttuurisesti ja historiallisesti muuntuvissa käytänteissä (esim. Kirkebæk 2005; Rantala, P. 2009; Ahlbeck 2015; ks. myös Kinnunen \& Hänninen 2016).

\section{Poikkeavuus audiovisuaalisen kerronnan kontekstissa}

Artikkelin teoreettiset lähtökohdat kiinnittyvät väljästi narratiiviseen tutkimusperinteeseen. Sitoudun traditioon, jossa kerronta ja kertomukset ymmärretään kontekstisidonnaisiksi käsitysten ja kokemusten sekä esimerkiksi itseä ja toisia koskevien tulkintojen konstruoinnin välineiksi (ks. Branigan 1992, 3; Berger 1997, 9-10; ks. myös Hägg 2010, 117-127). Analysoin Prinsessaa sanoista, kuvista ja äänistä rakentuvana merkityksellisenä kokonaisuutena, audiovisuaalisena narratiivina.

Kertomukset rakentuvat aina suhteessa jo aiemmin kerrottuun, ja siten myös Prinsessa on sidoksissa aihetta koskeviin toisiin teksteihin ja edeltäviin tulkintoihin. Toisin kuin tiukan teoslähtöisessä tai tekijän ${ }^{4}$ intentioihin keskittyvässä lähestymistavassa, korostan siis sosiokulttuurisen kontekstin merkitystä elokuvan rakentumisessa ja tulkinnassa. Edeltävät tulkinnat ovat erityisen keskeisiä tekstien luennassa, sillä kerronta nojaa aina vastaanottajiensa kulttuuriseen kompetenssiin, kykyyn hahmottaa se, mitä esimerkiksi median välittämät narratiivit viestivät (Berger 1997, 4, 12, 15). Tiukimman kannan mukaan yksikään teksti ei vielä itsessään ole kertomus, vaan vasta lukija luo siitä merkityksellisen kokonaisuuden ja tulkitsee sen kertomukseksi (Fludernik 2010, 18). Kulttuurinen tietovaranto mahdollistaa tekstien tulkinnan ja inhimillisen kyvyn merkityksellistää sellaisiakin asioita ja ilmiöitä - kuten Prinsessan kohdalla mielen sairauksia ja niistä kärsiviä ihmisiä -, joista tekstien vastaanottajilla ei välttämättä ole henkilökohtaisia kokemuksia (Bamberg 2004, 359-360; Birch 2012, 85-86; ks. myös Bacon 2000, 14, 47-48).

Ennen yhteiskunnan medioitumista mielenterveysongelmia ${ }^{5}$ koskeva kulttuurinen tieto välittyi pitkälti suullisena perinteenä, folklorena (ks. Kinnunen 2015). Nykypäivänä audiovisuaalinen kerronta on kulttuurisen tiedon muotoutumisprosessissa keskeisellä sijalla. Medioituminen on johtanut paitsi mediateknologian voimakkaaseen lisääntymiseen ihmisten arjessa, myös siihen, että tavat kokea ja ymmärtää maailmaa ovat yhä enenevissä määrin eri medioiden kautta välittyneitä (Herkman 2001a, 18-20; ks. myös Herkman 2001b, 380). Mielenterveyspotilaiden sosiaalisen aseman kannalta tällä on ollut problemaattinen, harhaluuloja ruokkiva vaikutus, sillä elokuvien ja televisiosarjojen esittämät tulkinnat ovat usein olleet mielisairaiden poikkeavuutta korostavia (ks. esim. Hyler \& al. 1991; Diefenbach 1997).
4 Prinsessan ohjaaja Arto Halonen on lähestynyt emotionaalisesti latautuneita aiheita myös muissa ohjaustöissään, kuten dokumenttielokuvassa Valkoinen raivo (Suomi 2015), jossa käsitellään koulukiusaamista ja väkivaltafantasioita. Tässä artikkelissa fokus ei kuitenkaan ole ohjaajan intentioiden selvittämisessä, sillä näkemykseni on, että kulttuuristen tekstien tekijät eivät voi milloinkaan täysin lukita tekstiensä saamia tulkintoja (ks. Bacon 2000, 215). Lisäksi käsitän tekijän todellisen tekijän sijasta sisäistekijäksi eli tekstistä abstrahoitavissa olevaksi hypoteettiseksi tekijäksi (ks. Chatman 1978, 147-151). Prinsessan sisäistekijän hahmotan tekijäksi, joka on sidoksissa hulluuden problematiikkaa käsitteleviin edeltäviin kertomuksiin mutta joka toisaalta tiedostaa tämän ja kykenee ainakin osittain myös haastamaan vakiintuneita kulttuurisia tulkintoja.

5 Mielenterveysongelmat ja -häiriöt ovat laajoja yläkäsitteitä, joiden piiriin luetaan erilaisia ja eriasteisia mielenterveyden ja käyttäytymisen häiriöitä, kuten syömis- ja persoonallisuushäiriöitä sekä alkoholinkäytön aiheuttamia käyttäytymisen häiriöitä (ks. Psykiatrian luokituskäsikirja 2012). Kuhunkin häiriöön, kuten esimerkiksi erilaisiin addiktioihin, liittyy osin eriytynyttä mediakuvastoa (ks. esim. Rantala V. 2013). Tässä artikkelissa viittaan mielenterveysongelmilla ja niiden mediarepresentaatioilla vakavina pidettyihin, laitoshoitoa vaativiin mielisairauksiin, kuten skitsofreniaan, josta myös Prinsessan päähenkilön kerrotaan kärsivän. 
Poikkeavuudella (engl. deviance) tarkoitetaan sellaisia ominaisuuksia ja käyttäytymisen muotoja, joiden katsotaan ylittävän normatiiviset kehykset koskien sitä, mikä on kulloinkin odotuksenmukaista, suotavaa ja normaalia (Kitsuse 1962, 248; Becker 1963, 8-9; Jokinen \& al. 2012, 190-192). Poikkeavuutta tuotetaan ja ylläpidetään toiminnassa, jota nimitän erilaisuuden rajankäynniksi. Ymmärrän erilaisuuden rajankäynnin muun muassa median välityksellä tapahtuvaksi sosiaaliseksi toiminnaksi, eräänlaiseksi jatkuvaksi kulttuuriseksi neuvotteluksi, jossa konstruoidaan käsityksiä asioiden, ilmiöiden ja ihmisten ominaisuuksista, keskinäisistä suhteista ja eroista. Tässä neuvottelussa syntyy käsityksiä yhtäältä siitä, mikä on tervettä ja normaalia, sekä toisaalta siitä, mikä on sairasta ja epänormaalia, poikkeavaa. Silloin, kun poikkeavuus nähdään kielteisenä, ulkopuolisena ja puutteellisena erilaisuutena, voidaan puhua myös toiseudesta (Hall 1999, 160, 189-192; Löytty 2005, 8-9; Hänninen 2013, 10).

Länsimaisessa kulttuurissa psyykkisesti sairastavat ihmiset ovat tummaihoisten (ks. Hall 1999) ja seksuaalivähemmistöjen (ks. Gross 1998) ohella yksi niistä poikkeaviksi toisiksi toistuvasti esitetyistä ihmisryhmistä, joiden kärjistettyjä piirteitä vasten me-ryhmän edustajat ovat peilanneet ja vahvistaneet omaa identiteettiään. Mieleltään erilaisiksi katsottuihin ihmisiin on toki ajoittain liitetty myös positiivisia vivahteita, kuten uskomuksia kyvystä nähdä ja hallita salattua tietoa. Kuitenkin myös visionäärinen "hullu" oli yhtä lailla poikkeava; hän oli omalaatuinen yksilö, jolla uskottiin olevan yhteys toiseen todellisuuteen ja tietoon, jota normaaliksi katsottu yhteisön enemmistö ei kyennyt tavoittamaan. (Foucault 1988, 21-22.)

Useimmiten psyykkisesti sairastavien ihmisten erilaisuus on esitetty negatiivisena poikkeavuutena. Tällaiset tulkinnat saivat konkreettisimman ja kauaskantoisimman ilmiasunsa 1800-1900-lukujen taitteen laajassa kotimaisessa ja yleiseurooppalaisessa tieteellis-yhteiskunnallisessa keskustelussa, johon kietoutui käsityksiä rotuhygieniasta ja kansakunnan rappeutumisesta, degeneraatiosta. Mielisairaat leimattiin rikollisiin rinnastuviksi, henkisiltä ja fyysisiltä ominaisuuksiltaan rappeutuneiksi toisiksi, joiden perinnölliseksi uskotut ominaisuudet ja eläimelliset taipumukset - kuten eritoten naispotilaiden hillittömäksi kuviteltu sukupuolivietti ja löyhä moraali - näyttäytyivät laajana yhteiskunnallisena ongelmana (ks. Hirvonen 2004; Hietala 2009; ks. myös Kirkebæk 2005).

Osa vuosisadan takaisessa yhteiskunnallisessa keskustelussa esitetyistä tulkinnoista on sittemmin jatkanut elämäänsä länsimaisessa audiovisuaalisessa mediassa. Esimerkiksi käsitys seksuaalisesta, viettelijätär-tyyppisestä nuoresta naispotilaasta on ollut toistuvasti yksi mielisairauden tematiikkaa käsittelevien elokuvien yleisimmistä stereotyypeistä (ks. Hyler \& al. 1991, 1045-1046). Useat suositut kauhuelokuvat, kuten Halloween (Halloween, USA 1978) ja Psyko (Psycho, USA 1960), taas ovat uusintaneet käsitystä mielisairauksista kärsivien ihmisten taipumuksesta yhteisöllistä järjestystä ja kanssaihmisten fyysistä koskemattomuutta uhkaavaan väkivaltaisuuteen. ${ }^{6}$ Kyseessä ei ole vain genresidonnainen ilmiö, vaan audiovisuaalisen median eri lajityypit ja välineet ovat hyödyntäneet laajalti käsitystä mielisairaiden vaarallisuudesta. Yhtenä esimerkkinä tästä mainittakoon suosittu kotimainen päivittäisdraama Salatut elämät, jonka kenties tunnetuin pahishahmo, mielenterveyden ongelmista kärsivä Aaro Vaalanne (Teemu Lehtilä), on aiheuttanut käytöksellään useita sarjan hurjimmista juonenkäänteistä.

Yksi merkittävimmistä syistä psyykkisesti sairastavien poikkeavuuden uusintamiselle audiovisuaalisessa kerronnassa lieneekin se, että poikkea-
6 Kauhugenressä on uusinnettu erityisesti väkivaltaisen ja murhanhimoisen mielisairaan stereotyyppiä. Halloweenissa teinejä jahtaava murhaaja on karannut mielisairaalasta, ja myös Psyko-elokuvien ikonisen pahiksen, Norman Batesin, kerrotaan olleen psykiatrisessa hoidossa. (Ks. Hyler \& al. 1991, 1045.) On esitetty, että elokuvien välittämät mielisairauden ja -sairaiden stereotyyppiset representaatiot - kuten eittämättä esimerkiksi Norman Batesin hahmo olisivat osaltaan ruokkineet länsimaisen lääketieteen ja psykiatrian kannalta virheellisiä käsityksiä esimerkiksi skitsofrenian ilmenemisestä jakautuneena persoonallisuutena (ks. Cross 2004, 198; Harper 2008, 170-171). 
vien hahmojen kärjistetyt piirteet toimivat kätevänä keinona sysätä henkilöt juonen kannalta oleellisiin, jännittäviin tilanteisiin (ks. Bacon 2000, 174-175). Poikkeavuudessa onkin usein kyse stereotyyppisestä, yksinkertaistavasta kulttuurisesta tiedosta, jota audiovisuaalinen kerronta herkästi hyödyntää. Stereotyyppiset henkilöhahmot ja juonikulut edesauttavat katsojaa ymmärtämään kerronnan syys-seuraus-suhteita ja hahmottamaan tekstin yhtenäiseksi kertomukseksi elokuvan rajallisen keston puitteissa (Bacon 2000, 38, 47, 174; ks. myös Herkman 2001a, 221-222). Elokuvakerronnan audiovisuaalisuuden voi myös ajatella tarjonneen verrattain hedelmällisen alustan länsimaiseen kulttuuriin syvälle juurtuneelle uskomukselle siitä, että ihmisen psyykkinen poikkeavuus heijastuu vastaavasti epänormaaliuksina yksilön eleissä ja ilmeissä sekä muussa fyysisessä olomuodossa (ks. Cross 2004, 197-200, 212; Gilman 2014).

Lähtökohtani on, että audiovisuaalinen kerronta siis yhtäältä kiinnittyy herkästi edeltäviin poikkeavuuden uusintamisen konventioihin, mutta samalla se on myös aina sidoksissa esittämisajankohtansa asenteisiin sekä poikkeavuuden kohtaamisen ja käsittelyn etiikkaan. Mielisairauden tematiikkaa audiovisuaalisessa mediassa tarkastelevan tutkimuksen piirissä tämä on osoitettu konkreettisimmin tutkittaessa intialaisia Bollywood-elokuvia useiden eri vuosikymmenien ajalta. Tällöin on havaittu, että elokuvien välittämät mielisairauden representaatiot myötäilevät yhteiskunnan poliittista ja sosiokulttuurista ilmapiiriä. Nousukaudet korreloivat verrattain positiivisina mielisairauden ja -sairaiden representaatioina, epävarmuuden kaudet taas negatiivisina. (Bhugra 2005; Malik \& al. 2011.)

Poikkeavuuteen ja siihen kohdistuvaan tutkimukseen liittyykin aina kaksi samanaikaista ulottuvuutta: Näkymiä avautuu yhtäältä siihen, kuka tai mikä on kussakin sosiokulttuurisessa kontekstissa nähty epänormaalina, ei-toivottuna ja ulkopuolisena. Samalla esille nousee se, mikä on koettu normaaliksi ja odotuksenmukaiseksi - ja millainen on ollut normaali, suotavana pidetty tapa kohdata ja käsitellä poikkeaviksi katsottuja ihmisiä. (Harjula 1996, 199; Kinnunen \& Hänninen 2016.) Lähestyn Prinsessaa ennen kaikkea nykykulttuurin tuotteena, kertomuksena, joka on sidoksissa paitsi edeltäviin myös tämänhetkisiin konventioihin ja normeihin koskien sitä, mitä ja miten poikkeavuudesta, mielen sairauksista ja niistä kärsivistä ihmisistä tulisi kertoa 2000-luvun kontekstissa.

\section{Lähiluvussa Prinsessa: artikkelin aineisto ja metodi}

Prinsessan juoni noudattaa löyhästi todellisen historiallisen henkilön, Anna Lappalaisen (1896-1988) elämänvaiheita. ${ }^{7}$ Lappalainen oli alun perin köyhän työläisperheen tytär, jonka elämässä alkoi 1930-luvun alussa lähes yhtenäisenä koko loppuelämän jatkunut laitoshoitokierre, jonka aikana hänellä diagnosoitiin muun muassa skitsofrenia. Piirre, joka erotti hänet potilastovereistaan ja sittemmin innoitti elokuvantekijöitä, oli hänen suuruusharhansa, vuosikymmeniä systemaattisena jatkunut kuvitelma siitä, että hän olisi alkuperältään kuninkaallinen prinsessa. (Raitasuo \& Siltala 2010, 17-49.) Korostan, että käsitän elokuvan päähenkilön Prinsessaksi, joka on eri henkilö kuin Anna Lappalainen. "Prinsessa" on elokuvaa tuotettaessa ja sen vastaanotossa syntyvä rekonstruktio, henkilöhahmo, joka on Lappalaisen elämänvaiheita merkittävämmin sidoksissa kulttuurisiin ajattelutraditioihin ja kerronnan konventioihin.
7 Lappalaisen elämästä julkaistiin samoihin aikoihin elokuvan kanssa myös kirja Kellokosken Prinsessa (Raitasuo \& Siltala 2010). Kirja rakentuu faktoille, kun taas elokuvassa Lappalaisen elämäntarina asettaa kerronnalle raamit, joiden puitteissa annetaan tilaa myös sepitteelle. Elokuva muodostaa kirjaa hedelmällisemmän tutkimusmateriaalin, sillä sen korkeampi fiktiivisyyden aste, visuaalisuus ja elokuvakerronnalle tyypilliset, poikkeavuuden uusintamiselle herkät konventiot kiinnittävät sen kirjaa voimakkaammin hulluuden problematiikkaan kytkeytyviin kulttuurisiin ajattelun ja kerronnan traditioihin. 
Olen katsonut Prinsessaa toistuvasti useiden eri vuosien aikana, ja ymmärrän jokaisen katselukerran osaksi aineiston analyysia ja tulkintaa. ${ }^{8}$ Aluksi katsoin elokuvaa kokonaisuutena, alusta loppuun. Vähitellen katsominen muuttui lukutavaksi, jossa huomio kiinnittyi tiettyihin jaksoihin ja kohtauksiin sekä niiden keskinäiseen vertailuun ja rinnastamiseen. Lopulta nostin elokuvasta tarkan analyysin kohteeksi kolme avainkohtaukseksi tulkitsemaani kohtausta, joiden luku-ja analyysitapaani nimitän lähiluvuksi. Lähiluku on narratiiviseen teoriaperinteeseen kytkeytyvä, kirjallisuudentutkimuksen piirissä alun perin syntynyt väljä analyyttinen metodi, joka on sittemmin omaksuttu soveltaen myös toisille tieteenaloille. Sen luonteeseen kuuluu verrattain suppeiden tekstiaineistojen toistuva, mahdollisimman tarkka lukeminen. (Pöysä 2010, 331-344; Pöysä 2015, 26-33.)

Lähilukua on perinteisesti sovellettu kirjoitettujen tekstiaineistojen, kuten kaunokirjallisuuden ja muistelukerronnan analyysissa. Se toimii kuitenkin erinomaisesti myös audiovisuaalista aineistoa analysoitaessa, sillä se ikään kuin pakottaa suuntaamaan huomiota eleiden ja ilmeiden kaltaisiin, audiovisuaaliselle kerronnalle ominaisiin nyansseihin. Analysoinkin kohtauksia kerrontana, jossa erilaisuuden rajankäynti tapahtuu paitsi puheen myös kuvakulmien, ilmeiden ja katseiden kaltaisten nonverbaalien yksityiskohtien kautta (ks. myös Branigan 1992, 33-34; Rantala, V. 2013). Vaikka analysoin tarkasti vain kolmea verrattain lyhyttä kohtausta, tulkitsen ja kontekstualisoin niitä jatkuvasti suhteessa sekä elokuvaan kokonaisuutena että toisiin yksittäisiin kohtauksiin, sillä kohtausten merkitykset rakentuvat, syventyvät ja saavat uusia merkityksiä vuorovaikutuksessa edellä ja jatkossa kerrottuun. Kyseessä on siis eräänlainen hermeneuttinen kehä, jossa kokonaisuus muodostuu yksittäisistä kohtauksista ja yksittäiset kohtaukset saavat merkityksensä suhteessa kokonaisuuteen.

Analysoimani kohtaukset ajoittuvat suhteellisen tasaisesti eri puolille elokuvaa: ensimmäinen elokuvan alkupuolelle, toinen puolivälin tienoille ja kolmas loppupuolelle. Juuri kolmen kohtauksen valintaan päädyin havaittuani, että elokuvan draaman kaari noudattaa tiukasti aristoteelista kolmen näytöksen mallia, jossa kullakin osiolla on oma kestonsa ja funktionsa (ks. Bacon 2000, 98-118). Olen valinnut lähiluvun kohteeksi yhden kohtauksen kustakin osiosta. Prinsessan ensimmäisessä, neljäsosan kokonaiskestosta kattavassa osiossa katsoja tutustutetaan henkilöhahmoihin ja asetetaan juonen kannalta olennaiset ristiriidat ja ongelmat. Ongelmien kärjistyminen tapahtuu toisessa, puolet kestosta kattavassa osiossa, jonka puoliväliin ajoittuu juonen kulkuun merkittävästi vaikuttava taitekohta. Kolmannessa, neljäsosan kokonaiskestosta kattavassa loppuosiossa tapahtuu ongelmien ratkaisu. Valitsemalla lähiluvun kohteeksi yhden kohtauksen elokuvan kustakin osiosta olen pyrkinyt huomioimaan henkilöhahmojen suhteissa ja erilaisuuden rajankäynnissä kerronnan kuluessa mahdollisesti tapahtuvat muutokset.

Prinsessan tarinamaailmassa liikutaan kronologisesti pääasiassa 1940-50-luvuilla. Kerronta alkaa vuodesta 1945, jolloin Prinsessa (Katja Kukkola) saapuu hoitoon Kellokosken sairaalaan. Siellä hän kohtaa erilaisia potilaita ja hoitohenkilökunnan jäseniä, joista keskeiseksi muodostuu lääkäri Grotenfelt (Samuli Edelmann). Grotenfelt on voimakastahtoinen lääkäri, joka tahtoisi uudistaa sairaalassa käytettäviä hoitomuotoja aloittamalla lobotomiat. ${ }^{9}$ Ylilääkäri Soininen (Antti Litja) päättää kuitenkin pitäytyä vanhoissa hoitomuodoissa, mikä turhauttaa Grotenfeltia. Prinsessan ja Grotenfeltin välinen jännite ja siihen limittyvä kamppailu käytettävistä hoitomuodoista on elokuvan keskeisin,
8 Ensimmäisen kerran näin Prinsessan elokuvateatterissa syksyllä 2010. Sittemmin katsoin elokuvaa toistuvasti käyttäessäni sitä yhtenä aineistokorpuksena pro gradu -tutkielmassani (Kinnunen 2012). Syksyllä 2015 palasin elokuvan pariin aloittaessani tämän artikkelin työstämisen.

9 Lobotomia on 1930-luvulla kehitelty psykokirurginen erityisesti skitsofrenian hoitoon suunnattu - toimenpide, jossa potilaan otsalohkojen yhteydet taemmas aivoihin katkaistaan. Lobotomiaa pidettiin aluksi lupaavana hoitomuotona, ja sen isänä pidetty portugalilainen neurologi Egas Moniz palkittiinkin keksinnöstään Nobelilla vuonna 1949. Suomalaisessa psykiatriassa lobotomia otettiin käyttöön vuonna 1946, minkä jälkeen lobotomialeikkauksia tehtiin Suomen mielisairaaloissa yleisesti noin kahden vuosikymmenen ajan. (Salminen 2011; Herva 2013; Pietikäinen 2013, 228-241.) 
kantava teema. Olenkin valinnut analysoimani kohtaukset siten, että niistä jokainen liittyy kiinteästi Prinsessan ja Grotenfeltin väliseen dynamiikkaan.
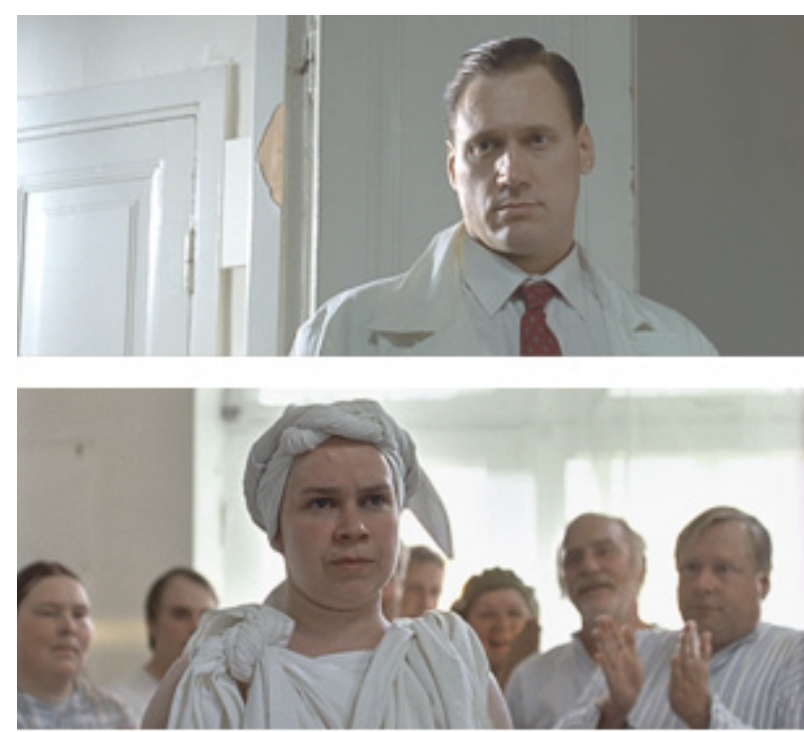

Prinsessan ja lääkäri Grotenfeltin välinen jännite on elokuvan kantava teema. Henkilöhahmojen välistä dynamiikkaa ilmennetään kerronnassa muun muassa katseiden ja kuvakulmien suunnilla. Kuvat: kuvakaappaukset DVD:Itä.

Elokuvan aloittavasta osiosta olen valinnut lähiluvun kohteeksi kohtauksen, jossa Prinsessalle annetaan ensimmäistä kertaa shokkihoitoa. ${ }^{10}$ Kohtaus on samalla yksi ensimmäisiä Prinsessan ja Grotenfeltin välisiä tapaamisia, ja siinä tunnustellaan ja haetaan keskushenkilöiden välisiä hierarkkisia positioita. Toinen lähilukemani kohtaus ajoittuu elokuvan toiseen osioon, aikaan ennen elokuvan puolivälin taitekohtaa. ${ }^{11}$ Kohtauksessa Grotenfelt juo päiväkahvia yhdessä ylilääkäri Soinisen, lääkäri Longan (Paavo Westerberg) ja ylihoitaja Pakalénin (Irma Junnilainen) kanssa. Prinsessa itse ei ole kohtauksessa läsnä, mutta hän on keskustelun kohde, sillä kahvittelijat pohtivat, mitä tämän prinsessakuvitelmien kanssa tulisi tehdä - myös potilaan mahdollinen onnellisuus nostetaan esille. Kohtauksessa esitetty lyhyt dialogi tarjoaa mielenkiintoisen, elokuvan keskeisintä sanomaa reflektoivan ja kiteyttävän näkökulman poikkeavuuden määrittämiseen ja siihen suhtautumiseen.

Prinsessan puolivälin taitekohdaksi ajoittuvat ylilääkäri Soinisen läksiäiset: Soininen siirtyy toisiin tehtäviin, minkä seurauksena Grotenfelt astuu ylilääkärin virkaan ja sairaalassa aloitetaan lobotomiat. Uusi ylilääkäri pyrkii saamaan Prinsessan leikattavaksi mahdollisimman pian, mutta tämän sijasta ensimmäisenä leikkaukseen päätyykin toinen potilas, Kuronen (Pirkka-Pekka Petelius). Läpi elokuvan jatkunut, Grotenfeltin ja Prinsessan välinen kamppailu huipentuu viimein elokuvan kolmannessa, päättävässä osiossa. Tästä osiosta olen nostanut lähiluvun kohteeksi eräänlaiseksi kerronnan kliimaksiksi tulkitsemani kohtauksen, jossa Grotenfelt on viimein onnistunut saamaan Prinsessan leikkauspöydälle odottamaan lobotomiaa. ${ }^{12}$ Verrattuna ensimmäiseen analysoimaani kohtaukseen kyseinen kohtaus tarjoaa uudenlaisen, osin muuttuneen näkökulman keskushenkilöiden väliseen dynamiikkaan. Prinsessan kolmas osio - ja siten koko elokuva - päättyy epilogiin, jonka kerronnassa hypätään 1950-luvulta vuoteen 1988 ja Prinsessan kuolinvuoteelle Nikkilän mielisairaalaan. Samalla kuva siirtyy Kellokoskelle ja vanhentuneeseen Grotenfeltiin, joka vaikuttaa ikään kuin vaistoavan entisen potilaansa kuolinhetken.
10 Kohdassa 5.52-7.27. Kohtauksen kesto yhteensä $1 \mathrm{~min}$ $35 \mathrm{~s}$. Elokuvan kokonaiskesto yhteensä 1.37.48.

11 Kohdassa 36.47-37.37. Kohtauksen kesto yhteensä $50 \mathrm{~s}$.

12 Kohdassa 1.22.421.24.03. Kohtauksen kesto yhteensä $1 \mathrm{~min} 21 \mathrm{~s}$. 
Seuraavaksi siirryn aineiston analyysiin. Ensimmäisessä analyysiluvussa toteutan mikrotasoista, tarkkaa lähilukua, joka etenee kohtaus kohtaukselta: aloitan elokuvan ensimmäisestä osiosta lähiluvun kohteeksi valitsemastani kohtauksesta, ja päädyn lopulta elokuvan viimeisestä osiosta esille nostamaani kolmanteen kohtaukseen. Näin pyrin tuomaan esille Prinsessan kerronnallisen luonteen, jossa asioidentilat ja henkilöhahmojen suhteet elävät ja muuttuvat kerronnan edetessä. Toisessa analyysiluvussa pohdin lähiluvun keinoin tekemieni havaintojen merkitystä suhteessa laajempaan kulttuuriseen kontekstiin.

\section{Katse elokuvaan ja poikkeavuuden rajoille}

Elokuvan ensimmäiseen osioon ajoittuva lähilukemani kohtaus alkaa Prinsessan maatessa sängyssä. Hoitajat valmistelevat häntä shokkihoitoon kiristämällä vuoteen ympärille remmejä, jotta potilas pysyisi hoidon aikana aloillaan. Edeltävässä kohtauksessa vastikään sairaalaan saapunut Prinsessa on tanssinut sairaalan parvekkeella muiden potilaiden ympäröimänä, mutta tanssiminen on keskeytynyt lääkäreiden saapuessa paikalle. Sanoja ei ole vaihdettu, vaan kohtaus on päättynyt Prinsessan ja Grotenfeltin totiseen katsekontaktiin, minkä jälkeen kerronnassa on edetty elokuvan ensimmäiseen shokkihoitokohtaukseen. Kaikkiaan elokuvassa on useita shokkihoitokohtauksia, ja merkityksellistä on, että ne on asetettu seuraamaan välittömästi kohtauksia, joissa on tapahtunut jonkinlainen konflikti. Tässä tapauksessa kyse on siis tanssimisesta, joka rikkoo sairaalan arkisia rutiineja ja aiheuttaa hämmennystä. Lisäksi tulkitsen tanssimisen ja sen aiheuttaman hämmennyksen kytkeytyvän tansseihin pitkään liitettyyn turmiollisuuteen ja potentiaaliseen seksuaalisuuteen, mitä Prinsessan naiseus edelleen korostaa. ${ }^{13}$

Prinsessan halu itseilmaisuun ja oman kehon vapaaseen liikuttamiseen pyritään saamaan hallintaan. Tämä ilmaistaan kohtauksessa konkreettisesti sitomalla potilaan keho sänkyyn ja antamalla tälle shokkihoitoa, minkä seurauksena potilas ei enää itse kykene hallitsemaan omaa kehoaan. Vastaavasti toisaalla elokuvassa shokkihoitoa edeltää sairaalan jumalanpalvelus, jossa yksi Prinsessan läheisimmistä potilastovereista, Kuronen, keskeyttää papin saarnan alkaen esittää omia uskonnollisia tulkintojaan. Shokkihoidot siis seuraavat
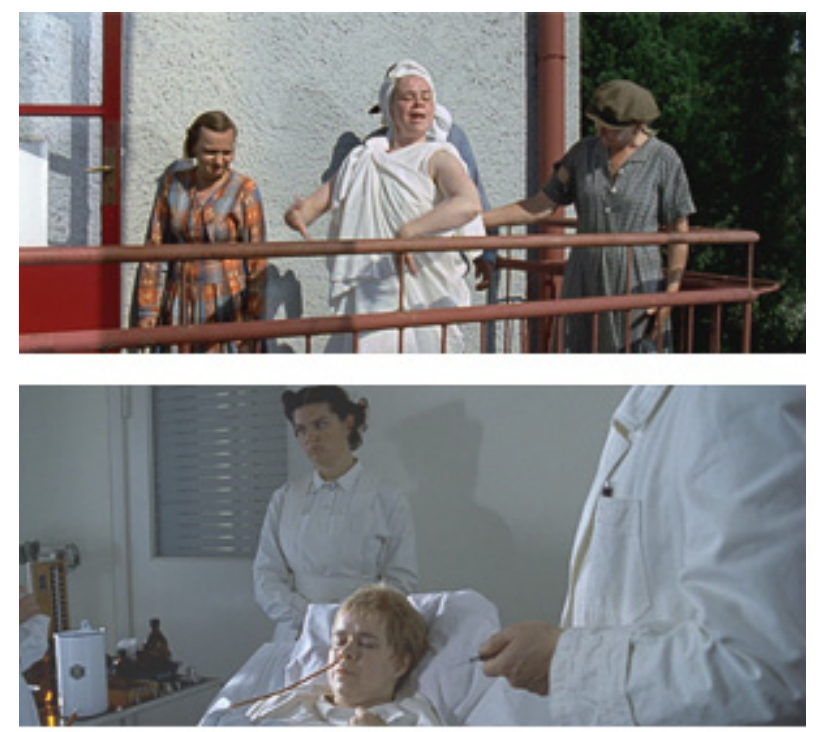

Shokkihoidot seuraavat potilaiden puheita tai toimia, jotka henkilökunta katsoo sopimattomiksi. Prinsessalle aiheutetaan insuliinishokki ja -kooma sen jälkeen, kun hän on tanssinut luvatta sairaalan parvekkeella. Kuvat: kuvakaappaukset DVD:Itä.
13 Tanssimiseen liittyvä paheksunta nousee esille erityisesti elokuvan alkupuolelle ajoittuvassa kohtauksessa, jossa kaksi nuorta naishoitajaa keskustelee tanssikenkien ostamisesta. Toinen hoitajista toteaa, että aiheesta olisi syytä puhua varovaisesti, jotta ylihoitaja Pakalén ei kuule asiasta, sillä "tässä sairaalassa ei hoitajat tanssi - eikä potilaat". Repliikin loppuosa on suunnattu kohtauksessa läsnä olevalle, potilassängyssään makaavalle Prinsessalle, joka tekee käsillään tanssimiseen viittaavia eleitä. 
elokuvassa toistuvasti potilaiden toimia tai puheita, jotka henkilökunta katsoo sopimattomiksi. Tämä haastaa katsojan arvioimaan, onko normirikkeen ja sitä seuraavan sanktion välinen suhde ymmärrettävä ja oikeudenmukainen.

Kohtauksen edetessä Grotenfelt poimii lääkeruiskun käsiinsä samalla, kun hänen takanaan välähtää ovella seisovan potilas Kurosen hahmo. Grotenfelt huomaa Kurosen, kun tämä lausuu äkkiä eräänlaisen eettisen kehotuksen: "Vastuu kannustakoon hoitohenkilökuntaa." Kuronen ja Grotenfelt käyvät tämän jälkeen lyhyen keskustelun siitä, miksi Kuronen, jonka tulisi olla työterapiassa, onkin osastolla. Keskustelun päätteeksi Grotenfelt korostaa valtaansa kääntämällä Kuroselle selkänsä ja antamalla hoitajille lievästi ärtyneen kuuloisen käskyn: "Viekää joku se nyt sinne töihinsä." Kuronen viedään pois, mutta elokuvan puoliväliin saakka hän on aktiivinen henkilöhahmo, joka ilmestyy vastaavalla tavalla useisiin kohtauksiin ja esittää puhuttelevia, filosofisesti ja teologisesti sävyttyneitä repliikkejä, jotka kutsuvat katsojaa pohtimaan potilaiden kohtelua ja mielisairaanhoidon vaiheita.

Potilas Kurosen kohtalo on traaginen: pian elokuvan puolivälin jälkeen hänelle tehdään lobotomia, minkä jälkeen hän esiintyy yhä useissa kohtauksissa mutta ei enää koskaan puhu. Kuvaavaa on, että kohtauksessa, jossa lobotomia suoritetaan, Kuronen esittää viimeiseen asti ajatuksiaan kunnes hänet kirjaimellisesti hiljennetään. Katsojalle jää - tai pikemminkin jätetään - epäselväksi se, miksi Kuronen oikeastaan on mielisairaalassa, sillä hänen sairaudestaan ei kerrota mitään. Oikeastaan Kuronen muuttuu poikkeavaksi toiseksi vasta leikkauksen jälkeen, sillä tällöin katsojan huomio kiinnittyy paitsi hahmon puhumattomuuteen, myös siihen, että lobotomian jälkeen Kuronen kävelee aina nurinkurisesti, selkä menosuuntaan. Myös Prinsessan kohdalla sairaus jää kerronnassa taka-alalle, ja katsojassa herätetään kysymys, ovatko potilaan prinsessakuvitelmat sairauden aiheuttamia harhoja vai olisiko kyseessä vain tietoinen rooli. Teeskentelyn mahdollisuutta korostetaan elokuvan ensimmäiseen osioon ajoittuvassa kohtauksessa, jossa Grotenfelt kysyy kollegaltaan Longalta, miten Prinsessan kuvitelmiin tulisi suhtautua: "Mitä sä luulet, teeskenteleekö se? Pitääkö se meitä pilkkanaan?" Longan vastausta ei näytetä, vaan kysymys jätetään katsojan itsensä pohdittavaksi.

Kurosen poistuttua Prinsessaan pistetään insuliinia, minkä jälkeen hoitajat pitelevät tämän tärisevää kehoa paikoillaan. Lääkäri seisoo sängyn äärellä ja katsoo alaspäin kohti potilasta, toimenpiteiden passiivista kohdetta, joka on menettänyt kontrollin ja päätäntävallan omasta kehostaan. Aikaisemmin samassa kohtauksessa Grotenfelt asemoi Prinsessaa hierarkkisesti alapuolelleen rinnastamalla tätä eläimeen toteamalla, että "meillä oli perheessä aikanaan kissa, jonka nimi oli Anna, sekään ei paljon puhunut". Grotenfelt pyrkiikin saamaan Prinsessan puhumaan, sillä sairaalaan saapumisen jälkeen tämä ei vielä ole sanonut sanaakaan. Kuten Kurosen kohtalo osoittaa, pelkkä puhuminen ei kuitenkaan vielä riitä, vaan puheen tulisi olla toivotunlaista, lääkäreiden terveeksi ja soveliaaksi määrittämää.

Prinsessan heräillessä insuliinikoomasta Grotenfelt seisoo jälleen sängyn äärellä ja katsoo vuoteessa makaavaa potilasta. Hän esittää Prinsessalle muutamia kysymyksiä testaten tämän ajan- ja paikantajua, mutta potilas ei vastaa. Kohtauksen viimeisenä, jälleen vastauksetta jäävänä kysymyksenä lääkäri tiedustelee Prinsessalta, ymmärtääkö tämä, "että minä yritän auttaa". Kuvakulma on suunnattu sängyllä makaavaan Prinsessaan, mutta etualalla näkyy Grotenfeltin lääkeruiskua pitelevä käsi. Kohtaus uusintaa kuvakulmien ja katseiden suuntien kautta totunnaista lääkärin ja potilaan välistä hierarkkista asetelmaa. Samalla - tekemällä asetelman korostuneen näkyväksi - sitä 
pyritään kuitenkin myös kyseenalaistamaan. Apu, jota lääkeruiskua merkityksellisesti kädessään pitelevä lääkäri tarjoaa, on fyysistä ja voimallista, potilaan kehoon peruuttamattomastikin vaikuttavaa. Tämä haastaa katsojan pohtimaan, onko tällainen apu tarpeellista, saati eettistä. Ja onko päähenkilö oikeastaan sairas vai olisiko kyse pikemminkin erilaisuudesta, joka ei asetu ihanteellista ihmistä määrittäviin aikalaisnormeihin? Onko Prinsessa eronneena, ruumiilliseen itseilmaisuun pyrkivänä taiteellisena naisena, joka on tehnyt kabareetanssijan ja hierojan työtä, liian etäällä esimerkiksi soveliasta ja kelvollista naiseutta määrittävistä normeista? ${ }^{14}$

Prinsessan ja Grotenfeltin välinen jännite kasvaa, kun Prinsessa ryhtyy puhumaan ja ilmoittaa olevansa prinsessa. Grotenfelt vastustaa Prinsessan puheita voimakkaasti, mutta osa muusta hoitohenkilökunnasta alkaa alkuhämmennyksestä selvittyään suhtautua prinsessakuvitelmiin suopeasti. Tämä aiheuttaa henkilökunnan välille jännitteitä, jotka nousevat esille lähilukemassani, elokuvan toiseen osioon ajoittuvassa kohtauksessa. Grotenfelt juo kohtauksessa kahvia aurinkoisena, kauniina kesäpäivänä sairaalan edustalle katetun pöydän ääressä yhdessä kollegoidensa kanssa. Tätä on edeltänyt hyväntuulisen elokuvamusiikin säestämä lyhyt kohtaus, jossa Lonka sivuuttaa Prinsessan käytävällä: Prinsessa tanssii, mitä Lonka jää hetkeksi seuraamaan, hymyilee ja taputtaa käsiään. Kuten eleistä voi päätellä, Lonka olisi taipuvainen hyväksymään Prinsessan harhan, ja päiväkahvipöydässä hän avaa keskustelun aiheesta:

Lonka: Mä luulen, että Lappalaisen kohdalla tämä prinsessana oleminen pitäisi hyväksyä.

Grotenfelt (nauraen): Ei jumalauta!

Pakalén: Että mentäisiin mukaan hänen harhaansa?

Lonka: Mikä muukaan tässä auttaisi?

Grotenfelt: Lonka, se ei edistä harhan poistumista, päinvastoin.

Pakalén: Ryhdytäänkö me kaikki potilaiksi?

Grotenfelt: Melkoinen maine tulisikin, oikea houruin hoitola.

Lonka: Miksi hänen ei annettaisi olla prinsessa? Kylältä tulee viestejä, kuinka hän piristää ihmisiä. Sitä paitsi hänhän on onnellisempi kuin yksikään koko henkilökunnasta.

Pakalén (hymyillen): Ettei tohtori nyt sekoittaisi tunteita työhön?

Grotenfelt: Ehkä Lonka kaipaa itsekin sähköshokkeja!

Lonka on verrattain lempeä henkilöhahmo, jonka piirteitä vasten Grotenfeltin voimakas tahto ja Prinsessaa koskevat mielipiteet korostuvat. Grotenfelt pyrkii muuttamaan Prinsessaa, mutta Lonka kyseenalaistaa tämän kysyen, miksi potilaan ei annettaisi olla sellainen kuin tämä on - varsinkin, kun potilas vaikuttaa onnelliselta. Lonka kuitenkin tyrmätään, ja kollegat esittävät nauraen, että mahdollisesti myös Longalle itselleen tulisi antaa sähköshokkeja. Shokkihoidot ja niiden uhka näyttäytyvät jälleen - vaikkakin nyt humoristisessa valossa - sopimattomina ja poikkeavina pidettyjen ajatusten seurauksina.

Kohtaus korostaa poikkeavuuden määrittymisen keinotekoisuutta. Tätä alleviivaa paitsi käyty dialogi myös kohtauksessa läsnä oleva ylilääkäri Soininen, joka ei osallistu keskusteluun vaan juo hiljaisena kahvia ja kaivaa yhdessä lähikuvassa sormella hampaitaan. Soininen on ylilääkärinä sairaalahierarkian huipulla, mutta toisaalta hän on käytöksensä osalta usein juuri se, joka kiinnittää huomiota - se, joka rikkoo asemaansa kohdistuvia odotuksia. Elokuvassa on esimerkiksi kohtaus, jossa Prinsessa kohtaa yllättäen tokkuraisen ja puolipukeisen Soinisen, jonka työpöydältä löytyy lääkeruisku ja -pullo. Kerronnassa
14 Erityisesti 1900-luvun alun mielisairaanhoidon kohdalla on puhuttu gynekologisesta psykiatriasta, jossa naisen keho oli usein miespuolisten lääkäreiden tarkastelun ja patologisoinnin kohteena. Toiseuttavan katseen kohteeksi joutuivat erityisesti ne naiset, jotka rikkoivat seksuaalisen käyttäytymisensä osalta käsitystä siveästä, perhekeskeisestä ihannenaisesta. (Kirkebæk 2005; Ahlbeck 2015.) Sittemmin käsitystä seksuaalisesti aktiivisesta, mielenterveysongelmaisesta viettelijättärestä on toistettu audiovisuaalisessa mediassa (ks. Hyler \& al. 1991, 10451046). Prinsessassa tällainen hahmo on Prinsessan potilastoveri ja hovineito Christina von Heyroth (Krista Kosonen), joka esimerkiksi riisuu itsensä useissa kohtauksissa alasti. Prinsessa paheksuu hovineitonsa käyttäytymistä, mutta kuitenkin myös hän itse viittaa kertaalleen omaan seksuaalisuuteensa tilanteessa, jossa Grotenfelt on tullut käymään potilaan huoneessa. Prinsessa tekee lääkärille yllättävän seksuaalisen ehdotuksen todetessaan äkisti, että "nyt olisi saunapuhdasta, mutta kun se on niin piukkaa". 
annetaan ymmärtää, että Soininen kärsii morfiiniriippuvuudesta, mikä johtaa hänen siirtoonsa pois sairaalan ylilääkärin virasta. Soinisen hahmo ilmentää potilaiden ja henkilökunnan välisten rajojen häilyvyyttä - houruinhoitola voisi yhtä lailla, toisesta näkökulmasta katsoen olla myös houruin hoitola, mihin analysoimani kohtauksen dialogissa implisiittisesti viitataan.
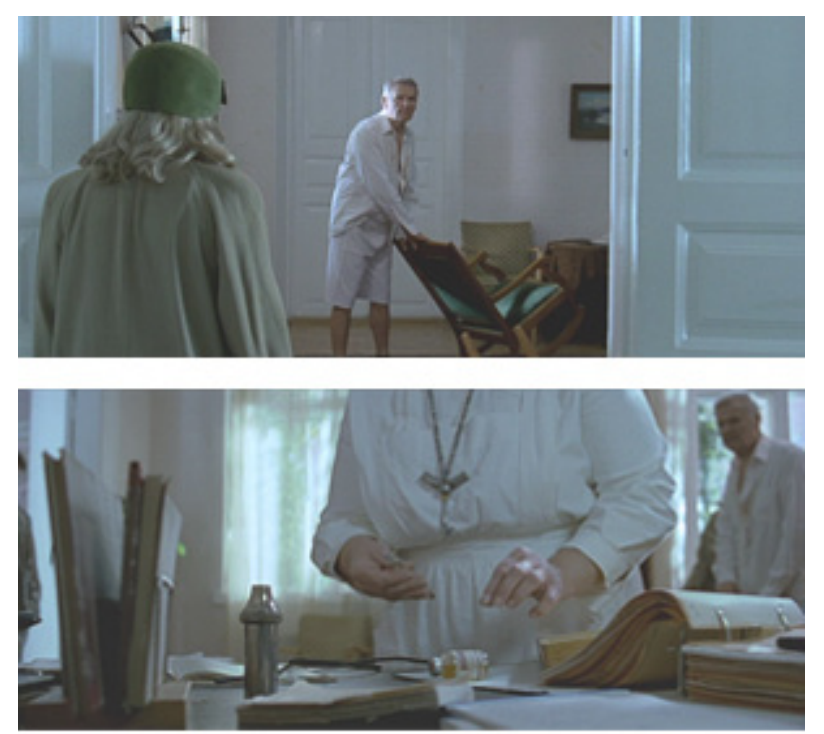

Morfiinitokkuraisen ylilääkäri Soinisen hahmo korostaa poikkeavuuden määrittymisen keinotekoisuutta. Kuvat: kuvakaappaukset DVD:Itä.

Grotenfeltin astuminen ylilääkärin virkaan elokuvan puolivälissä on merkittävä käänne. Ylilääkärinä hän on viimein vapaa toteuttamaan tahtoaan ja aloittamaan lobotomiat, mutta samalla erityisesti viran entisen haltijan, Soinisen, käytös aiheuttaa katsojassa kysymykseen siitä, onko valta nytkään oikeissa käsissä ja miten tätä tulisi arvioida. Uusi ylilääkäri pyrkii saamaan Prinsessan leikattavaksi mahdollisimman pian, mutta tämä onnistuu kuitenkin välttämään leikkauksen. Kuitenkin lopulta, elokuvan viimeisessä osiossa, seuraa kolmas lähilukemani kohtaus, jossa Prinsessa makaa leikkauspöydällä valmiina lobotomiaan.

Leikkaussali on harmaansävyinen tila, jossa ovat Prinsessan ja Grotenfeltin ohella läsnä lobotomiakirurgi Mäkelä (Pertti Koivula), lääkäri Lonka, ylihoitaja Pakalén ja kaksi hoitajaa. Grotenfelt ja Mäkelä sijoittuvat seinän syvennykseen upotetun vapahtaja-patsaan eteen. Tämä korostaa ylilääkärin ja leikkaavan kirurgin miltei rajatonta valtaa mutta toisaalta herättää myös kysymyksen tämän vallan alkuperästä, seurauksista ja eettisyydestä. Grotenfelt seisoo Prinsessan vierellä ja tarkkailee tätä jälleen totisena, ylhäältä alaspäin suunnatulla katseella. Prinsessa - uhmakas ja Grotenfeltin tavoin voimakastahtoinen hahmo - on tähän saakka onnistunut välttämään leikkauksen, mutta nyt ylilääkärin valta on viimein alistamassa hänet. Äkkiä Mäkelä ilmoittaa kuitenkin kuulleensa lääkintöhallituksesta, että "leikkauksista ollaan luopumassa ristiriitaisten tulosten vuoksi". Hänen mukaansa lobotomialeikkauksia ei nyt suositella mutta lisää, että päätäntävalta asian suhteen on yhä sairaalalla. Grotenfelt pysyy kannassaan toteuttaa lobotomia, mikä aiheuttaa Longassa voimakkaan vastareaktion: "Voi herrajumala, minä en voi olla mukana tällaisessa teurastuksessa." Lonka poistuu salista perässään hoitajat ja viimein myös ylihoitaja Pakalén. Ylilääkärin valta on äkkiä supistunut olemattomiin, ja lobotomia jää tekemättä. 
Prinsessan kliimaksin voi katsoa päättyvän ylilääkärin tappioon ja potilaan voittoon. Toisin kuin Kurosen kohdalla, päähenkilön keho ja mieli säilyvät kutakuinkin eheinä ja koskemattomina. Lopputulos on erittäin mielenkiintoinen, sillä kulttuuristen konventioiden mukaisesti Prinsessassa tulisi mielisairaalapotilaana olla jotain poikkeavaa, muutosta vaativaa. Asettamalla hänet rooliin, jonka näkökulmasta kerronta usein suodattuu ja johon katsojan sympatia kohdistuu, on seurauksena tilanne, jossa katsoja on jatkuvasti pakotettu arvioimaan päähenkilön ominaisuuksia ja niiden uskottua erilaisuutta. Katsoja joutuu - ja hänet myös tarkoituksellisesti jätetään - pohtimaan, mitä Prinsessan poikkeavuus oikeastaan on ja mikä olisi oikeanlainen, sovelias tapa suhtautua siihen.

\section{Katseen laajentaminen: Prinsessa 2000-luvulla tuotettuna poikkeavuuden representaationa}

Lähilukemieni kohtausten perusteella esitän, että Prinsessan keskeisin sanoma on, että poikkeavuuden ja normaaliuden sekä sairauden ja terveyden rajat ovat aina keinotekoisia ja kontekstisidonnaisia. Samoin kuin elokuvan mainoslause, myös elokuva kokonaisuutena pyrkii siis hämmentämään kulttuurisia mielikuvia mielenterveyspotilaiden yksioikoisesta poikkeavuudesta. Millaisia merkityksiä elokuva keskeisine sanomineen sitten saa, kun sitä pohtii 2000-luvun tuotteena, kertomuksena, joka kiinnittyy mielenterveysongelmia ja poikkeavuutta koskeviin nykykulttuurille ominaisiin tulkintoihin?

On merkityksellistä, että juuri lobotomia on nostettu elokuvassa keskeiseen asemaan. Lobotomiaan suhtauduttiin aikanaan innostuneesti (Salminen 2011, 48-49; Herva 2013), mutta sittemmin sitä on pidetty epäinhimillisenä menetelmänä ja yhtenä länsimaisen mielisairaanhoidon suurimmista virhearvioinneista. Kärkkäimmissä tulkinnoissa lobotomia on esitetty sosiaalisena kontrollina, jossa ei ollut kyse niinkään yrityksestä parantaa tai lievittää potilaan sairautta vaan pikemminkin pyrkimyksestä suitsia sopimattomana pidettyä käyttäytymistä (Donaldson 2005, 39). ${ }^{15}$ Myös Prinsessasta on erotettavissa arvottavia, tahallisen anakronistisia sävyjä lobotomialeikkauksia kohtaan, mitä tuodaan esille erityisesti Kurosen hahmon kautta. ${ }^{16}$ Kurosen sairautta ei nimetä tai määritellä tarkemmin, ja oikeastaan hän vaikuttaa vain älykkäältä, filosofisiin ja teologisiin kysymyksiin laajasti perehtyneeltä henkilöltä. Hänelle tehtävä lobotomia näyttäytyy sairauden parantamisyrityksen sijasta kontrollin keinona, jolla Kurosen ajatukset ja puheet voimallisesti ja lopullisesti vaiennetaan.

Lobotomiaa koskeva kriittinen ote kiinnittää Prinsessan osaksi laajempaa medikalisaatiokriittistä keskustelua. Kyseinen keskustelu virisi Yhdysvalloissa 1960-70-luvuilla etupäässä Irving Kenneth Zolan (1972) ajattelun myötä, mutta Suomessa se on saanut kunnolla jalansijaa vasta 1990-luvulta lähtien (Lahelma 2003, 1863-1864, 1866-1867). Medikalisaatiolla viitataan lääketieteen vahvistumiseen, mutta se voidaan liittää myös kehitykseen, jossa yhä useammat inhimilliset ominaisuudet ja erot ymmärretään sairauden oireiksi. Patologisoinnin kohteeksi joutuvat usein sellaiset käyttäytymisen muodot, kokemukset tai kokonaiset ihmisryhmät, jotka näyttäytyvät valtakulttuurin silmissä epäterveinä ja vallitsevia arvoja uhkaavina - toisin sanoen kyse on usein sosiaalisesta kontrollista. (Conrad 1992; Barnet 2012; ks. myös Pietikäinen 2013, 394-396.)
15 Lobotomia eräänlaisena sosiaalisen kontrollin välineenä on puhuttanut viime aikoina myös tieteellisen keskustelun ulkopuolella. Syksyllä 2015 iltapäivälehdissä oli näkyvästi esillä presidentti John F. Kennedyn siskon elämäntarina. Parikymppiselle Rosemary Kennedylle tehtiin 1940-luvun alussa lobotomia, ja siihen johtaneiksi syiksi iltapäivälehdet esittivät esimerkiksi tarpeen suitsia Rosemaryn seksuaalista aktiivisuutta. Esimerkiksi Ilta-Sanomat julkaisi 5.10.2015 aihetta käsittelevän lobotomiaa kriittisesti arvottavan artikkelin otsikolla "JFK:n hävetyn sisaren julmasta kohtalosta kohistaan USA:ssa - lobotomia tuhosi Rosemaryn" (ks. <http:// www.iltasanomat.fi/ulkomaat/ art-2000001013701.html>, linkki tarkistettu 22.9.2016).

16 Henkilöhahmona Kuronen on stereotyyppi. Esimerkiksi Steven E. Hyler ja kumppanit (1991, 1046) ovat erottaneet eräänlaisen valistuneen kansalaisen hahmon (engl. enlightened member of society) yhdeksi hulluuden tematiikkaa käsittelevien elokuvien toistetuimmista, stereotyyppisimmistä henkilöhahmoista. 
Mielisairaanhoidon historiassa psykiatrian kehitystä on totuttu pitämään positiivisena kehityskulkuna, mitä se osaltaan onkin. Medikalisaatiota olisi kuitenkin osattava tarkastella myös kriittisesti ymmärtäen, että kaikkien olemisen ja käyttäytymisen ilmenemismuotojen kohdalla yksioikoinen jako terveeseen ja patologiseen ei välttämättä ole inhimilliseltä kannalta arvioiden paras tai edes tarpeellinen ratkaisu. ${ }^{17}$ Prinsessassa korostetaankin toistuvasti potilas Kurosen ja ylilääkäri Soinisen hahmojen kautta kriittistä näkemystä, jonka mukaan poikkeavuutta ja sairautta määriteltäessä ja käsiteltäessä on aina olemassa myös vaihtoehtoisia tulkintakehikkoja, jotka saattavat kääntää normaalin ja patologisen väliset rajat jopa päinvastaisiksi. ${ }^{18}$
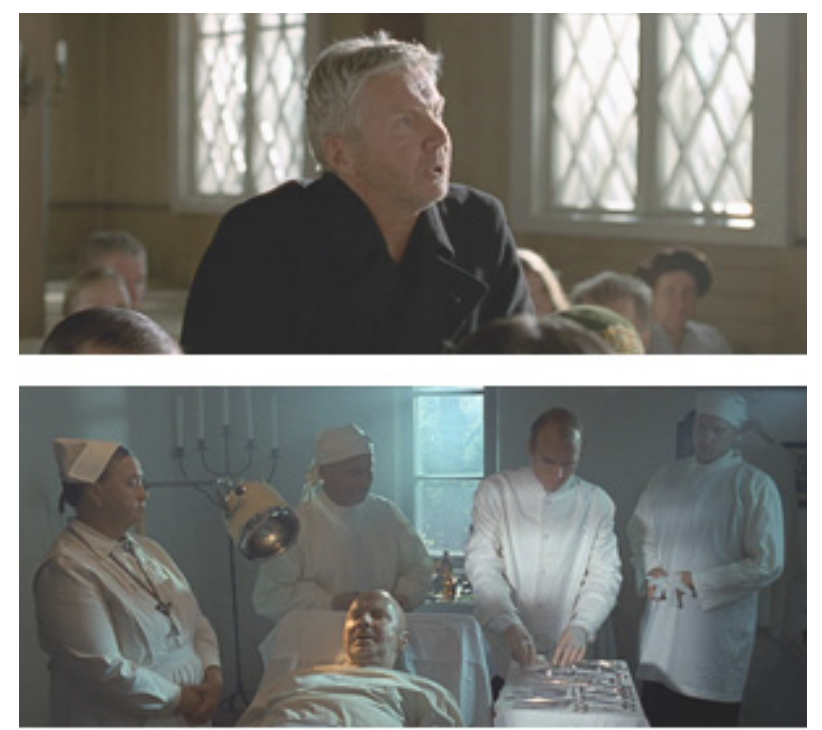

Prinsessassa lobotomia esitetään sosiaalisen kontrollin keinona. Kurosen ajatukset vaiennetaan lobotomialla, minkä jälkeen potilas ei enää koskaan puhu. Kuvat: kuvakaappaukset DVD:Itä.

Poikkeavuuden kohtaaminen on aina kietoutunut tiukasti kulttuuriseen arvomaailmaan. Viimeaikaisessa poikkeavuuden määrittymistä tarkastelevassa tutkimuksessa tämä on osoitettu Prinsessan tulkinnan kannalta olennaisella tavalla Pälvi Rantalan (2009) väitöstutkimuksessa, jossa tarkastellaan 1800-luvulla elänyttä torniolaista persoonallisuutta, Kalkkimaan pappia, koskevia eriaikaisia ja erilaisissa aineistoissa sittemmin esitettyjä tulkintoja. 1880-luvulta lähtien Kalkkimaan pappi on esitetty kontekstista riippuen milloin kotiseutua ja ihanteellista kansalaisuutta edustavana runoilijana, milloin taas rahvaanomaisena maaseutuköyhälistön edustajana. Kohti nykyaikaa tultaessa tulkinnoissa on korostunut Kalkkimaan papin yksilöllisyys, jota on kuvattu jopa ihaillen todisteena siitä, että kyseinen henkilö ei halunnut alistua tarjottuihin muotteihin. Tämän Rantala tulkitsee heijastavan erilaisuuden ihailtavuutta nykyaikana ja toteaa, että "menneisyyden ihmisistä samastumiskohteeksi valitaan se, joka eniten tuntuu muistuttavan oman aikamme ihanneihmistä". Tällä hetkellä aikamme ihanneihminen on Rantalan mukaan "yksilöllinen ja erikoinen oman tiensä kulkija". (Rantala, P. 2009, 292-293.) Kuten Prinsessan lähiluku osoittaa, elokuvassa päähenkilön poikkeavuus esitetään niin ikään yksilöllisenä, ihailtavankin vahvana persoonallisuutena, jonka Grotenfelt pyrkii tuloksetta alistamaan sopivina pitämiinsä ihmisyyden ja naiseuden muotteihin. Samalla Kurosen kohtalon avulla tuodaan esille, kritisoidaan ja varoitetaankin, millaiseen lopputulokseen poikkeavuuden normalisoimiseen tähtäävät toimet voivat johtaa.
17 Äänten kuuleminen on yksi esimerkki kokemuksista, jotka nykylääketiede ja -psykiatria herkästi patologisoi. Äänten kuulemiseen liittyvää patologisointia on kuitenkin pyritty purkamaan erityisesti parin viime vuosikymmenen aikana mistä yhtenä osoituksena on vuonna 1996 perustettu Suomen Moniääniset ry. Kyseinen yhdistys pyrkii edistämään ääniä kuulevien jäsentensä hyvinvointia muun muassa painottamalla, että äänten kuuleminen on mahdollista käsittää ja hyväksyä inhimilliseksi ominaisuudeksi, johon löytyy herkkyys jokaisesta inmisestä (Ks. <www.moniaaniset.fi>, linkki tarkistettu 20.9.2016.)

18 Täysin uniikkina Prinsessan medikalisaatiokriittistä otetta ei kuitenkaan voida pitää. Suhteutettuna muihin samaa teemaa käsitteleviin elokuviin voidaan havaita, että vastaavanlaatuisia tulkintoja on esitetty aikaisemminkin. Esimerkiksi Yksi lensi yli käenpesän -menestyselokuvassa suhteellisen terveen oloisena sairaalaan saapuvalle päähenkilölle tehdään lopulta lobotomia. Tähänkin elokuvaan liitettiin markkinoinnissa puhutteleva retorinen kysymys: "If he is crazy, what does that make you?" Kysymys kutsuu katsojaa pohtimaan itsen ja muiden välisiä yhtäläisyyksiä ja eroja. Kyseiseen elokuvaan verrattuna Prinsessassa on kuitenkin erilaista se, että juuri potilas on alun alkaenkin se, jonka näkökulmasta poikkeavuuden ja normaaliuden välisten rajojen määrittymisen keinotekoisuutta ilmennetään. 
Tulkitsen Prinsessan kriittiseksi kannanotoksi koskien poikkeavuuden yksioikoista, mustavalkoista patologisointia. Se, mikä on elokuvan suhde (vakaviin) psyykkisiin sairauksiin, jää kuitenkin osin epäselväksi. Erityisesti Prinsessan ja Kurosen kohdalla katsoja joutuu toistuvasti pohtimaan, ovatko nämä hahmot psyykkisesti sairaita vai sittenkin vain massasta erottuvia vahvoja persoonallisuuksia. Kurosen kohdalla diagnoosia ei mainita lainkaan, ja Prinsessan taas kerrotaan sairastavan skitsofreniaa, mutta sairauden olemassaoloa ilmennetään pääasiassa vain sitä vastaan osoitetuilla shokkihoidoilla. Tämä kyllä korostaa terveyden ja sairauden välisten rajojen määrittämisen vaikeutta, mutta samalla se synnyttää vääjäämättä myös kysymyksen siitä, onko elokuvan emansipatorinen ote tullut mahdolliseksi vain siten, että vakavien mielenterveysongelmien esittäminen ja reflektointi on jätetty kerronnassa taka-alalle.

Joidenkin kansainvälisten tutkimusten mukaan suhtautuminen mielenterveysongelmiin olisi 2000-luvulle tultaessa muuttunut myönteisemmäksi. Esimerkiksi Jo C. Phelan ja kumppanit (2000) ovat kuitenkin huomauttaneet laajan vertailevan aineistonsa pohjalta, että aiempaa myönteisempi suhtautuminen mielisairauksiin olisi seurausta siitä, että ihmiset käsittävät mielenterveysongelmiksi nykyään myös joukon psykooseja ja skitsofreniaa lievempiä psyykkisiä häiriöitä, kuten masennuksen. Phelanin tutkimusryhmän mukaan lientynyt suhtautuminen koskeekin vain lieviä mielenterveyden häiriöitä, kun taas vakavia mielenterveysongelmia koskevat tulkinnat ovat yhä negatiivisten mielikuvien sävyttämiä. (Phelan \& al. 2000, 188, 191, 200, 202.) ${ }^{19}$ Prinsessankin kohdalla voidaan kysyä, millaisen sävyn elokuva olisi saanut, jos päähenkilön skitsofrenia olisi nostettu näkyvämmin esille. Kohdistuuko elokuvan verrattain positiivinen, hyväksyvä katse siis ensisijaisesti persoonalliseen erilaisuuteen ja lieviin mielenterveyden häiriöihin - eikä näin ollen niinkään vakaviin psyykkisiin sairauksiin?

Myös Prinsessan huumorilla on tulkinnan kannalta kaksijakoinen merkitys. Huumori on läpi elokuvan keskeisessä asemassa, kuten analysoimassani kohtauksessa, jossa lääkäri Lonkaa uhataan humoristisesti sähköshokeilla, mikäli hän ei luovu näkemyksestään hyväksyä Prinsessan harha. Kevyt huumori keventää tunnelmaa ja osoittaa henkilökunnan ja potilaiden välisten erojen ja hierarkioiden keinotekoisuutta, mutta liitettäessä mielenterveysongelmat ja huumori toisiinsa liikutaan kuitenkin aina alueella, jossa astutaan herkästi myös poikkeavuutta uusintaviin konventioihin. Eroa meidän ja muiden välillä on aina tuotettu myös nauraen, osoittamalla muiden poikkeavuutta ja ulkopuolisuutta huumorin keinoin (Knuuttila 1992, 145-147; Herkman 2001b, 374,377). Prinsessassa nauru ei kohdistu ainoastaan potilaisiin vaan yhtä lailla myös henkilökunnan jäseniin - kuten lääkäri Lonkaan - mutta elokuvassa on kuitenkin toistuvasti myös sellaisia kohtauksia, joissa nimenomaan potilaat aiheuttavat koomisen tilanteen. Kerronnan emansipatorisesta yleissävystä huolimatta potilaat ovat siis 2000-luvulla tuotetussa Prinsessakin usein niitä, joiden normeja rikkovia puheita, eleitä ja toimia kohti nauru suuntautuu.

Huolimatta siitä, että Prinsessassa pyritään medikalisaatiokriittiseen ja ymmärtävään otteeseen, kaikkien yksityiskohtiensa osalta kerronnassa ei siis kuitenkaan täysin kyetä erkanemaan tematiikkaan liittyvistä problemaattisista konventioista. Tämä ilmenee kuvaavasti lähilukemassani kohtauksessa, jossa hoitohenkilökunta keskustelee päähenkilön prinsessakuvitelmista ja mahdollisesta onnellisuudesta. Kohtauksen miljöö on kaunis ja aurinkoinen, ja elokuvassa kokonaisuutena onkin toistuvasti samankaltaisia kesäisiä, miltei paratiisimaisia ulkokohtauksia. Yhtäältä tämä näyttäytyy aktiivisena,
19 Myös suomalaisten suhtautumista mielenterveysongelmiin vuosittain mittaavan mielenterveysbarometrin mukaan hyväksyntä mielenterveyspotilaita kohtaan on - joskin hyvin hitaasti - kasvamassa (ks. Mielenterveysbarometri 2015, <http://mtkl.fi/wp-content/uploads/2015/11/Mielenterveysbarometri-2015.pdf>, linkki tarkistettu 20.5.2016). Ennakkoluulot skitsofreniaa kohtaan istuvat kuitenkin edelleen tiukassa, sillä kolmasosa suomalaisista ei edelläänkään haluaisi skitsofreenikkoa naapurikseen (ks. Mielenterveysbarometri 2015: Nimbymittari eli keitä suomalaiset eivät haluaisi naapureikseen, <http://mtkl.fi/wp-content/ uploads/2015/11/Mielenterveysbarometri-2015-Nimbymittari.pdf>, linkki tarkistettu 20.5.2016). 
eksplisiittisenä pyrkimyksenä kyseenalaistaa ja kritisoida psyykkisten sairauksien tematiikkaan liittyviä kielteisiä mielikuvia. Toisaalta tällä on kuitenkin ambivalentti kääntöpuolensa, joka luo kokonaisuuteen implisiittisen, ikään kuin tahattoman särön. Ajatus siitä, että mielisairaalat olivat paratiisimaisia ja niiden potilaat olivat onnellisia, on kieltämättä kaunis ja osaltaan mahdollinenkin - mutta onko se samalla myös romantisoitunut näkemys, joka loppujen lopuksi vapauttaa nykykatsojan vastuusta siitä, millaisia traagisiakin seurauksia mielen sairauksista kärsivien ihmisten toiseuttamisella on historian saatossa ollut?

\section{Lopuksi}

Prinsessa näyttäytyi jo ensisilmäyksellä - ehdottaessaan mainoslauseessaan mielisairaalapotilaan ja onnellisuuden kytköstä - elokuvana, jossa totutut kulttuuriset käsitykset olisivat liikkeessä. Edellä olen pureutunut tarkemmin elokuvan kerronnassa tapahtuvaan erilaisuuden rajankäyntiin. Olen selvittänyt, kuka tai mikä elokuvassa asemoidaan poikkeavaksi ja miten poikkeavuuden ja normaaliuden välisiä eroja tuotetaan ja tehdään näkyviksi. Kysymys on relevantti, sillä länsimaiseen kulttuuriin on kuulunut traditio, jossa mielen sairauksista kärsivät ihmiset on esitetty essentialistisesti poikkeaviksi toisiksi, joiden yksinkertaistettuja piirteitä vasten käsityksiä normaalina, terveenä ja soveliaana pidetystä on konstruoitu.

Elokuvan näkökulma psyykkisesti sairastaviin ihmisiin sekä poikkeavuuden määrittymiseen ja kohtaamiseen on hyväksyvä ja kulttuurisia konventioita kyseenalaistava, emansipatorinen. Sen kerronnassa jätetään tarkoituksellisen epäselväksi ja kontekstisidonnaiseksi se, kuka tai mikä oikeastaan edustaa normaaliutta ja kuka taas poikkeavuutta. Tämä saavutetaan horjuttamalla toistuvasti esimerkiksi henkilökunnan ja potilaiden - eli meidän ja muiden - välisiä konventionaalisia hierarkioita kutsumalla katsojaa pohtimaan normaaliuden ja poikkeavuuden sekä terveyden ja sairauden määrittymistä koskevia kysymyksiä: Miksi esimerkiksi Soininen on ylilääkäri, vaikka hän esiintyy toisinaan morfiinitokkurassa ilman ajan- ja paikantajua? Miksi taas Kuronen, filosofisesti ja teologisesti taitava ajattelija, on potilaan asemassa ja laitoshoidossa? Entä onko Prinsessa oikeastaan sairas vai olisiko hänen poikkeavuudessaan kyse pikemminkin sopimattomuudesta ihanteellista ihmistä ja naiseutta määrittäviin aikalaisnormeihin?

Olen käsitellyt Prinsessaa 2000-luvulla tuotettuna representaationa ja pyrkinyt pohtimaan, millaisia merkityksiä lähiluvun keinoin tekemäni havainnot saavat, kun niitä suhteuttaa laajempaan kulttuuriseen kontekstiin. Elokuvasta on havaittavissa yksityiskohtia, jotka liittävät sen osaksi medikalisaatiokriittisen keskustelun jatkumoa. Sekä shokkihoidot että erityisesti lobotomia esitetään elokuvassa sosiaalisen kontrollin keinoina, jotka seuraavat potilaiden esittämiä, henkilökunnan sopimattomiksi määrittämiä puheita ja tekoja. Tätä korostetaan erityisesti potilas Kurosen henkilöhahmon kautta, sillä oikeastaan Kuronen muuttuu puhumattomaksi, poikkeavaksi toiseksi vasta hänelle suoritettavan lobotomian jälkeen. Lääkäri Lonkaa taas uhataan leikillisesti sähköshokeilla, kun hän tohtii ehdottaa päähenkilön prinsessakuvitelmien hyväksymistä. Näin elokuvassa osoitetaan vallitsevien poikkeavuutta ja normaaliutta koskevien normien ja sanktioiden keinotekoisuus ja ajoittainen naurettavuuskin. Tulkitsen Prinsessan medikalisaatiokriittiseksi kannanotoksi, jossa kyseenalaistetaan käyttäytymisen mustavalkoinen jako 
terveeseen ja patologiseen. Elokuva tuntuu ikään kuin ehdottavan, että mikäli ihminen ei ole vaaraksi itselleen tai muille, miksi häntä oikeastaan tulisi muuttaa, normalisoida.

Prinsessan hyväksyvästä, emansipatorisesta otteesta huolimatta näkökulma vakaviin mielen sairauksiin jää osin epäselväksi, sillä esimerkiksi skitsofrenian reflektoinnilla ei ole kerronnassa keskeistä sijaa. Tämä kyllä yhtäältä osoittaa sairauden ja terveyden välisten rajojen määrittämisen vaikeutta, mutta toisaalta se jättää pohtimaan, millaisen sävyn elokuva olisi saanut, mikäli vakavina pidettyjen mielenterveysongelmien käsittely olisi nostettu nykyistä keskeisempään asemaan. Myös elokuvan huumori sekä erityisesti mielenterveyspotilaan onnellisuuden pohdinta ja mielisairaalamiljöön kauneuden korostaminen ovat ambivalentteja yksityiskohtia. Yhtäältä ne näyttäytyvät aktiivisena, tarkoituksellisena pyrkimyksenä kyseenalaistaa mielenterveyspotilaiden poikkeavuutta ja mielisairauksien synkkää kuvastoa. Implisiittisesti ne herättävät kuitenkin samalla myös toisenlaisia, problemaattisia mielleyhtymiä: jos mielisairaalapotilaat olivat kaikesta huolimatta onnellisia, tarvitseeko nykykatsojan reagoida siihen, kuinka kyseenalaisesti psyykkisesti sairastavia ihmisiä on kohdeltu - ja usein yhä edelleen kohdellaan?

Artikkelini kautta olen pyrkinyt suuntaamaan huomiota mielen sairauksien esittämiseen audiovisuaalisen median kontekstissa. Katsojalle kyse on esimerkiksi Prinsessan kohdalla ensisijaisesti viihteestä, mutta olisi kuitenkin tärkeää ymmärtää, että nykyaikana audiovisuaalinen media on usein ensisijainen kanava, jonka välityksellä mielenterveysongelmia ja psyykkisesti sairastavia ihmisiä koskeva kulttuurinen tieto konstruoituu. Ääntä ja kuvaa yhdistävänä, miltei kaikkialle ihmisten arkeen tunkeutuvana välineenä se on usein vielä painettua mediaakin voimakkaampi kulttuuristen mielikuvien ja mielipiteiden muokkaaja. Siksi elokuvienkaan välittämät representaatiot eivät ole yhdentekeviä - päinvastoin. Akateemisen tutkimuksen tehtävänä olisikin yhä enenevissä määrin pohtia, tehdä näkyväksi ja nostaa keskustelun kohteeksi niitä audiovisuaaliselle medialle ominaisia tulkintoja ja käytänteitä, joiden kautta käsityksiä mielen sairauksista ja niistä kärsivistä ihmisistä on tuotettu ja uusinnettu. Kun näiden usein problemaattisten, toiseuttavienkin käytänteiden rakentuminen tunnetaan, avautuu - parhaimmassa tapauksessa ja ajan kanssa - myös mahdollisuuksia niiden työstämiseen ja purkamiseen.

\section{Tutkimuskirjallisuus}

Ahlbeck, Jutta (2015) "Ratkaisuna sterilisaatio: Kansakunnan parasiitit ja naisruumiin uhka". Teoksessa Jutta Ahlbeck, Päivi Lappalainen, Kati Launis, Kirsi Tuohela \& Jasmine Westerlund (toim.) Kipupisteissä: Sairaus, kulttuuri ja modernisoituva Suomi. Turku: Utukirjat, 233-259.

Bacon, Henry (2000) Audiovisuaalisen kerronnan teoria. Helsinki: SKS.

Bamberg, Michael (2004) “Considering Counter Narratives”. Teoksessa Michael Bamberg \& Molly Andrews (toim.) Considering Counter-Narratives: Narrating, Resisting, Making Sense. Philadelphia: John Benjamins Publishing Company, 351-371.

Barnet, Robert J. (2012) “Medicalization of Life”. Canadian Dimension vol. 46:4.

Becker, Howard S. (1963) Outsiders. Studies in the Sociology of Deviance. New York: The Free Press. Berger, Arthur Asa (1997) Narratives in Popular Culture, Media and Everyday Life. Lontoo: SAGE. Bhugra, Dinesh (2005) “Mad Tales from Bollywood: The Impact of Social, Political, and Economic Climate on the Portrayal of Mental Illness in Hindi Films". Acta Psychiatrica Scandinavica vol. 112:4, 250-256. 
Birch, Michael (2011) Mediating Mental Health: Context, Debates and Analysis. Lontoo: Routledge. Branigan, Edward (1992) Narrative Comprehension and Film. Lontoo: Routledge.

Chatman, Seymour (1978) Story and Discourse: Narrative Structure in Fiction and Film. Ithaca: Cornell University Press.

Conrad, Peter (1992) "Medicalization and Social Control". Annual Review of Sociology vol. 18:1, 209-232.

Cross, Simon (2004) “Visualizing Madness: Mental Illness and Public Representation”. Television E New Media vol. 5:3, 197-216.

Diefenbach, Donald L. (1997) "The Portrayal of Mental Illness on Prime-Time Television". Journal of Community Psychology vol. 25:3, 289-302.

Domino, George (1983) "Impact of the Film "One Flew Over the Cuckoo's Nest" on Attitudes towards Mental Illness". Psychological Reports vol. 53:1, 179-182.

Donaldson, Elizabeth (2005) "The Psychiatric Gaze: Deviance and Disability in Film". Atenea vol. 25:1, 31-48.

Fludernik, Monika (2010) "Luonnollinen narratologia ja kognitiiviset parametrit". Teoksessa Mari Hatavara, Markku Lehtimäki \& Pekka Tammi (toim.) Luonnolliset ja luonnottomat kertomukset: Jälkiklassisen narratologian suuntia. Helsinki: Gaudeamus, 17-43.

Foucault, Michel (1988 [1965]) Madness and Civilization. A History of Insanity in the Age of Reason. New York: Vintage Books.

Gerbner, George (1959) "Mental Illness on Television: A Study of Censorship". Journal of Broadcasting vol. 3:4, 293-303.

Gilman, Sander L. (2014 [1982]) Seeing the Insane: A Visual and Cultural History of Our Attitudes Toward the Mentally Ill. Brattleboro, Vermont: Echo Point Books \& Media.

Gross, Larry (1998) "Minorities, Majorities and the Media". Teoksessa Tamar Liebes \& James Curran (toim.) Media, Ritual and Identity. Lontoo: Routledge, 87-102.

Hall, Stuart (1999) Identiteetti. Tampere: Vastapaino.

Harjula, Minna (1996) Vaillinaisuudella vaivatut: Vammaisuuden tulkinnat suomalaisessa huoltokeskustelussa 1800-luvun lopulta 1930-luvun lopulle. Helsinki: Suomen Historiallinen Seura.

Harper, Stephen (2008) “Understanding Mental Distress in Film and Media: A New Agenda?". The Journal of the Royal Society for the Promotion of Health vol. 128:4, 170-174.

Herkman, Juha (2001a) Audiovisuaalinen mediakulttuuri. Tampere: Vastapaino.

Herkman, Juha (2001b) “Huumorin ja vallan keskeneräinen kysymys: Populaarin kokemuksen jäljillä". Teoksessa Anu Koivunen, Susanna Paasonen \& Mari Pajala (toim.) Populaarin lumo: Mediat ja arki. Turku: Turun yliopisto, mediatutkimus, 368-384.

Herva, Riitta (2013) “Lobotomia oli oman aikansa tuote". Duodecim vol. 129, 1499-1501. Saatavilla: < http://www.terveysportti.fi/xmedia/duo/duo11117.pdf > (linkki tarkistettu 21.9.2016).

Hietala, Marjatta (2009) "Eugeniikan ja rotuhygienian tausta ja seuraukset". Tieteessä tapahtuu vol. 27:8, 14-19. Saatavilla: < http://ojs.tsv.fi/index.php/tt/article/view/2559/2363 > (linkki tarkistettu 20.9.2016).

Hirvonen, Helena (2004) "Mielisairauden saastuttamat: Mielisairaat perimän turmelijoina 1900-luvun alun suomalaisessa yhteiskunnassa". Lähde-historiatieteellinen aikakauskirja vol. 1:2, 145-160. Saatavilla: < http://www.lahde.info/EdellisetNrot/Lahde2-04.pdf > (linkki tarkistettu 21.9.2016).

Hyler, Steven E.; Gabbard, Glen O. \& Schneider, Irving (1991) “Homicidal Maniacs and Narcissistic Parasites: Stigmatization of Mentally Ill Persons in the Movies". Hospital and Cummunity Psychiatry vol. 42:10, 1044-1048.

Hägg, Samuli (2010) "Narratologisten käsitteiden soveltaminen kulttuurintutkimuksessa". Teoksessa Jyrki Pöysä, Helmi Järviluoma \& Sinikka Vakimo (toim.) Vaeltavat metodit. Joensuu: Suomen Kansantietouden Tutkijain Seura, 117-137.

Hämäläinen, Elina (2007) Hulluutta, neroutta, luovuutta? Skitsofrenian representaatioiden jäljillä elokuvassa Kaunis mieli. Teatterin ja draaman tutkimuksen pro gradu -tutkielma. Tampere: Tampereen yliopisto. Saatavilla:<https://tampub.uta.fi/bitstream/handle/10024/78456/gradu02153. pdf?sequence $=1>$ (linkki tarkistettu 7.7.2016).

Hänninen, Marja-Leena (2013) "Johdanto". Teoksessa Marja-Leena Hänninen (toim.) Vieras, outo, vihollinen: Toiseus antiikista uuden ajan alkuun. Helsinki: SKS, 9-20. 
Johnson, Davi A. (2008) “Managing Mr. Monk: Control and the Politics of Madness”. Critical Studies in Media Communication vol. 25:1, 28-47.

Jokinen, Arja; Juhila, Kirsi \& Suoninen, Eero (2012) Kategoriat, kulttuuri \& moraali: Johdatus kategoria-analyysiin. Tampere: Vastapaino.

Kinnunen, Anna (2012) Johtolankoja hulluuteen: Ilmiön kulttuurisen konstruoinnin tarkastelua. Perinteentutkimuksen pro gradu -tutkielma. Joensuu: Itä-Suomen yliopisto. Saatavilla: $<$ http:// epublications.uef.fi/pub/urn_nbn_fi_uef-20120082/urn_nbn_fi_uef-20120082.pdf > (linkki tarkistettu 7.7.2016).

Kinnunen, Anna (2015) “Mutta niille ei voi mitään, joilla on aivoissa vika: Mielisairauden kansanomaiset tulkinnat 1900-luvun alkuvuosikymmenten modernisoituvassa Suomessa". J@rgonia vol. 13:26, 30-53. Saatavilla: < https://jyx.jyu.fi/dspace/handle/123456789/48098 > (linkki tarkistettu 7.7.2016).

Kinnunen, Anna \& Hänninen, Kirsi (2016) "Saatteeksi: Hulluus kulttuurisena ilmiönä ja tutkimuskohteena". Elore vol. 23:1. Saatavilla: < http://www.elore.fi/elore-12016-vol-23-hulluus/ saatteeksi-hulluus-kulttuurisena-ilmiona-ja-tutkimuskohteena/ > (linkki tarkistettu 7.7.2016).

Kirkebæk, Birgit (2005) "Sexuality as Disability: The Women on Sprogø and Danish Society". Scandinavian Journal of Disability Research vol. 7:3-4, 194-205.

Kitsuse, John I. (1962) "Societal Reaction to Deviant Behavior: Problems of Theory and Method". Social Problems vol. 9:3, 247-256.

Knuuttila, Seppo (1992) Kansanhuumorin mieli: Kaskut maailmankuvan aineksina. Helsinki: SKS.

Lahelma, Eero (2003) "Medikalisaation juurilta nykypäivään". Duodecim vol. 119, 1863-1868. Saatavilla: < http://www.terveysportti.fi/xmedia/duo/duo93826.pdf > (linkki tarkistettu 7.7.2016).

Löytty, Olli (2005) “Johdanto: Toiseuttamista ja tilakurittomuutta”. Teoksessa Olli Löytty (toim.) Rajanylityksiä: Tutkimusreittejä toiseuden tuolle puolen. Helsinki: Gaudeamus, 7-24.

Malik, Mansoor; Trimzi, Imran \& Galluci, Gerard (2011) “Bollywood as Witness: Changing Perceptions of Mental Illness in India (1913-2010)". International Journal of Applied Psychoanalytic Studies vol. 8:2, 175-184.

Mullins, James (2014) "The Power of Media to Shape Perceptions of Mental Illness". Mental Health Practice vol. 17:8, 34-35.

Phelan, Jo C.; Link, Bruce G.; Stueve, Ann \& Pescosolido, Bernice A. (2000) “Public Conceptions of Mental Illness in 1950 and 1996: What is Mental Illness and Is It to be Feared?". Journal of Health and Social Behavior vol. 41:2, 188-207.

Pietikäinen, Petteri (2013) Hulluuden historia. Helsinki: Gaudeamus.

Psykiatrian luokituskäsikirja. Suomalaisen tautiluokitus ICD-10:n psykiatriaan liittyvät diagnoosit (2012). Helsinki: Terveyden ja hyvinvoinnin laitos.

Pöysä, Jyrki (2010) “Lähiluku vaeltavana käsitteenä ja tieteidenvälisenä metodina”. Teoksessa Jyrki Pöysä, Helmi Järviluoma \& Sinikka Vakimo (toim.) Vaeltavat metodit. Joensuu: Suomen Kansantietouden Tutkijain Seura, 331-360.

Pöysä, Jyrki (2015) Lähiluvun tieto: Näkökulmia kirjoitetun muistelukerronnan tutkimukseen. Joensuu: Suomen Kansantietouden Tutkijain Seura.

Raitasuo, Ilkka \& Siltala, Terhi (2010) Kellokosken Prinsessa. Helsinki: Like.

Rantala, Pälvi (2009) Erilaisia tapoja käyttää kylähullua: Kalkkimaan pappi aatteiden ja mentaliteettien tulkkina 1800-luvulta 2000-luvulle. Turku: K\&H-kustannus.

Rantala, Varpu (2013) "Techniques of the Invisible: Cinematic Images of Being Addicted". Nordic Studies on Alcohol and Drugs vol. 30:1-2, 105-122.

Salminen, Ville (2011) "Lobotomia psykiatrisena hoitomuotona Suomessa". Historiallinen aikakauskirja vol. 109:1, 48-59.

Signorielli, Nancy (1989) “The Stigma of Mental Illness on Television”. Journal of Broadcasting $\mathcal{E}$ Electronic Media vol. 33:3, 325-331.

Wahl, Otto \& Lefkowits, J. Yonatan (1989) “Impact of a Television Film on Attitudes toward Mental Illness". American Journal of Community Psychology vol. 17:4, 521-528.

Zola, Irving Kenneth (1972) "Medicine as an Institution of Social Control”. The Sociological Review vol. 20:4, 487-504. 